Зяйнитдинов Дамир Равильевич, аспирант кафедры «Микробиология, биотехнология и химия», Саратовский государственный аграрный университет имени Н.И. Вавилова. Россия.

410005, г. Саратов, ул. Соколовая, 335.

Тел.: (8542) 69-25-32.
Ключевые слова: глауконит; удобрение; тяжелые металль; сорбент; микроорганизмы; биоудобрения; иммобилизация на неорганических носителях; препаративная форма.

\title{
BIOTECHNOLOGICAL APPROACHES TO THE USE OF GLAUCONITE IN AGRICULTURE
}

Gorelnikova Elena Aleksandrovna, Candidate of Biological Sciences, Associate Professor of the chair "Microbiology, Biotechnology and Chemistry", Saratov State Agrarian University named after N.I. Vavilov. Russia.

Larionova Olga Sergeevna, Doctor of Biological Sciences, Associate Professor, Department of the chair "Microbiology, Biotechnology and Chemistry”, Saratov State Agrarian University named after N.I. Vavilov. Russia.

Hapcev Zaur Jur'evich, Candidate of Biological Sciences, Associate Professor of the chair "Microbiology, Biotechnology and Chemistry", Saratov State Agrarian University named after N.I. Vavilov. Russia.

Stepanov Sergey Alexandrivich, Doctor of Biological Sciences, Professor, Department of the chair "Microbiology, physiology of plants", National research Saratov State University named after N. G. Chernyshevsky. Russia.

Zjajnitdinov Damir Ravil'evich, Aspirant of the chair"Microbiology, Biotechnology and Chemistry", Saratov State Agrarian University named after N.I. Vavilov. Russia.
Keywords: glauconite; fertilizer; heavy metals; adsorbent; microorganisms; biofertilizers; immobilized on inorganic carriers; physical form.

We studied the efficiency of glauconite use as a natural sorbent in soils contaminated with heavy metals, as well as the possibility of its use as a natural mineral fertilizer. It has been shown that the addition of glauconite to soil contaminated with lead acetate and zinc sulfate leads to an increase in the total microbial number, micromycetes, actinomycetes and nitrogenfixing bacteria. They are determined main parameters of immobilization Agrobacterium radiobacter 204, Rhizobium leguminosarumbiovartrifoli, Flaviobacteriumfulvum L 30 on glauconite to create dry dosage forms of Biologicals. It was found that when creating dry dosage forms of biological product, the optimal ratios in the system of "biomass:glauconite" are 1:2 and 1:4 when dried for 24 hours at $22-24^{\circ} \mathrm{C}$. Introduction of the developed method of immobilization will help to prolong the viability of microorganisms in the biological product at the required level for 4 months.

удк $633.174,631.527$

\section{НОВЫЙ СОРТ ЗЕРНОВОГО СОРГО ЗЕРНЫШКО}

ГУСЕВ Владимир Васильевич, ФГБНУ «НИИСХ Юго-Востока»

ХАЛИКОВА Мадина Мустапаевна, ФГБНУ «НИИСХ Юго-Востока»

ЕСКОВА Вера Сергеевна, ФГБНУ «НИИСХ Юго-Востока»

ЛАРИНА Валентина Владимировна, ФГБНУ «НИИСХ Юго-Востока»

БАХАРЕВА Наталья Викторовна, ФГБНУ «НИИСХ Юго-Востока»

ХРАМОВ Александр Владимирович, ФГБНУ «НИИСХ Юго-Востока»

Показано, что новый сорт зернового сорго Зернышко обладает повышенной урожайностью, имеет пониженную влажность зерна при уборке. За годы изучения (2010-2016) урожайность зерна сорта Зернышко превышала стандарт на 1,63 m/га при уборочной влажности зерна 11,6 \%, у стандарта Перспективный 1 - 13,7\%. По содержанию крахмала (75,88 \%) превышал стандарт на 3,35\%. Семеноводство сорта надежно. Сорт предназначен для использования на фуражные цели и для производства крахмала.

Введение. В засушливых районах Поволжья, где часто повторяющиеся засухи резко снижают урожаи традиционных кормовых культур, стабилизация кормопроизводства является актуальной задачей. Решить ее поможет совершенствование структуры посевов кормовых культур за счет широкого внедрения наиболее засухоустойчивых. В данных условиях большую роль в сельском хозяйстве региона играет внедрение такой культуры, как сорго [8]. Это культура разностороннего использования. Биологические особенности сорго позволяют ей экономно расходовать влагу, приостанавливать рост при недостатке ее и возобновлять при выпадении осадков. Сорго в сравнении с другими яровы- ми культурами может формировать высокие и удовлетворительные урожаи зерна и зеленого корма в засушливые и исключительно сухие годы $[1,3]$.

По данным экспертно-аналитического центра агробизнеса «АБ-центр», по производству сорго Саратовская область стоит на 2-м месте в России $(59,8$ тыс. т, или 30,9 \% в общероссийских сборах сорго). Площади посева культуры непрерывно росли с 2011 по 2015 г. и достигли 73,2 тыс. га, что ставит регион на первое место в России по этому показателю $(32,6$ \% от общих площадей соргосеяния в РФ) [10]. В ФГБНУ «НИИСХ Юго-Востока» готовы предложить аграриям сельскохозяйственные куль- 
туры с наилучшими показателями. К ним относится и новый сорт зернового сорго Зернышко. Инорайонные сорта и гибриды из-за большей продолжительности вегетационного периода и высоких требований к теплу не вызревают в местных условиях. Все это обусловливает необходимость организации здесь селекционного процесса для создания хорошо адаптированных к местным условиям форм и совершенствования технологических вопросов для дальнейшего внедрения новых и распространения допущенных к использованию сортов и гибридов сорго $[2,5,7]$.

В связи с вышесказанным цель исследований - при селекции зернового сорго получить сорт, отличающийся повышенной урожайностью зерна, надежным семеноводством, хорошим качеством зерна, не уступающим стандарту, и пригодный для механизированной уборки серийными машинами.

Методика исследований. Чтобы получить элитное растение, в селекционном питомнике растения МC линии зернового сорго A-120c опылили раннеспелым сортообразцом зернового сорго (ПО-02-07) своей селекции. В последующем из F1 и следующих поколениях, применяя инцухт с направленным отбором, выделили элитное растение. В ходе исследований (20102016 гг.) был получен новый сорт Зернышко, стандартом служил сорт Перспективный 1.

Сорго - очень теплолюбивая культура. При посеве его в хорошо прогретую почву (15-16 ${ }^{\circ} \mathrm{C}$ на глубине заделки) всходы появляются на 7-8-й день. Ориентировочные сроки сева: в юго-восточных районах области - 10-15 мая, в приволжских - 1520 мая и в правобережных - 20-25 мая. Посев семенных участков нельзя затягивать, так как они могут быть повреждены осенними заморозками или им не хватит суммы положительных температур для формирования семян. Полевые опыты закладывали в соответствии с требованиями методики полевого опыта [4] и проводили на полях лаборатории селекции и семеноводства кормовых культур ФГБНУ «НИИСХ Юго-Востока». Посев осуществляли во второй - третьей декаде мая. Перед посевом проводили две культивации: первая - на глубину 15 см, вторая - на глубину заделки семян.
Климат отличается резкой континентальностью. Для него характерна холодная малоснежная зима, короткая засушливая весна и сухое жаркое лето. Сумма температур выше $10{ }^{\circ} \mathrm{C}$ составляет $2400-2800{ }^{\circ} \mathrm{C}$. Продолжительность безморозного периода 161 день, с колебаниями по годам от 119 до 195 дней. В целом погодные условия в годы исследований дали возможность реализовать максимальный продуктивный потенциал сорговых культур, что позволило объективно оценить биологические и хозяйственно-ценные признаки.

Результатьи исследований. По результатам исследований сорт Зернышко обладает повышенной урожайностью зерна: при стандартной влажности в среднем 4,54 т/га, превышая стандарт на 1,63 т/га (рис. 1). Максимальную урожайность зернового сорта Зернышко отмечали в 2013 г., а минимальную в 2010 г., превышая аналогичные значения стандарта на 3,42 и 1,43 т/га при НСР 1,38 и 0,24 т соответственно.

Новый сорт отличается ускоренными темпами начального роста, хорошо выровнен. Растения высотой 110-130см имеют 7-8 листьев. Листья зеленые, длина 29-43 см, без опушения. Жилка листа вначале светло-зеленая, по мере созревания светлеет (становится белой).

Метелка рыхлая, прямостоячая, средняя, симметричная, колосковые чешуи соломенного цвета, концы светло-коричневые. Зерно мелкое, открытое, хорошо вымолачивается, колоски остистые. Зерновка светло-коричневая, голая (без пленок), танин отсутствует. Эндосперм мучнистый белого цвета. Растения нового образца тонкостебельные, всходы зеленые, хорошо заметны, без антоциановой окраски.

Как видно из табл. 1, зерновое сорго Зернышко превышало стандарт за годы испытаний

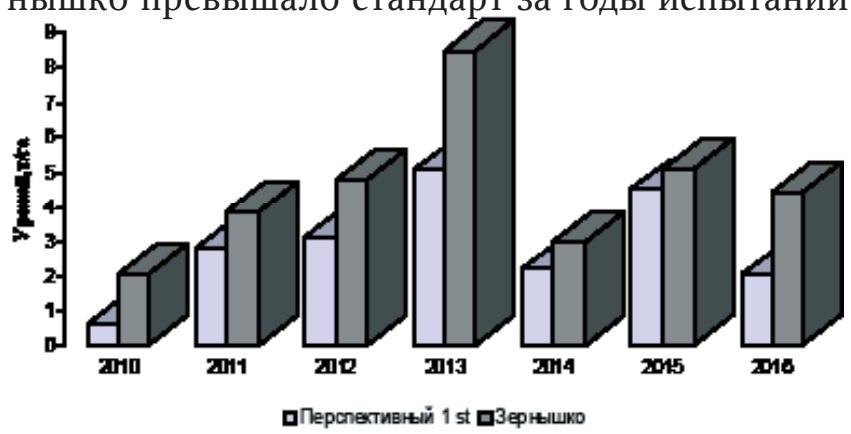

Рис. 1. Урожайность зернового сорта Зернышко и Перспективный 1 st за 2010-2016 z2.

Таблица 1

Структура урожая в КСИ зернового сорго в среднем за 2015-2016 гг.

\begin{tabular}{|c|c|c|c|c|}
\hline Вариант & $\begin{array}{c}\text { Количество } \\
\text { метелок }\end{array}$ & $\begin{array}{c}\text { Высота } \\
\text { растений, см }\end{array}$ & $\begin{array}{c}\text { Масса зерна } \\
\text { с } 1 \mathrm{M}^{2}, \Gamma\end{array}$ & $\begin{array}{c}\text { Масса } \\
\text { метелки, г }\end{array}$ \\
\hline Зернышко & 20 & 124 & 490 & 24 \\
\hline Перспективный 1 (st) & 33 & 113 & 292 & 22 \\
\hline
\end{tabular}




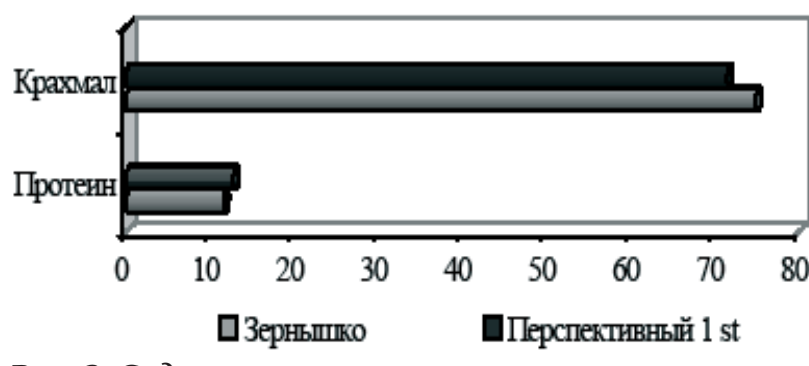

Рис. 2. Содержание сырого протеина и крахмала у сорта сорго Зернышко, \%

по массе зерна на 198 г с 1 м² и незначительно по массе метелки - на 2 г. Растения нового сорта превосходили стандарт по высоте, метелок сорта Зернышко было меньше на единице площади, но они были крупнее.

По содержанию сырого протеина $(12,09 \%)$ сорт уступал стандарту на 0,86 \%. По содержанию крахмала (74,92 \%) был больше стандарта на $3,42 \%$ (рис. 2).

Семеноводство зернового сорго осуществляется по традиционной для сорго технологии. Посев проводили на изолированном участке с пространственной изоляцией не менее 500 м. Семеноводческие посевы не должны идти после сорговых культур, что исключает биологическое засорение сорта. В период выметывания метелок (до цветения) для удаления примесей необходимо проводить сортовые прополки.

Широкое распространение сорго в основном сдерживается двумя факторами: недостатком высокоурожайных сортов и гибридов с гарантированным получением их семян в зоне возделывания и отсутствием налаженного семеноводства. Среди причин, значительно влияющих на величину и качество урожая, в первую очередь следует выделить способы посева, нормы высева, сроки и способы уборки семян. Оптимальное сочетание агроприемов и операций в системе семеноводства, особенно позиций дифференцированного адаптивного их применения, в зависимости от складывающихся метеорологических условий приобретает первостепенное значение.

Нормы высева, способы посева и уборки сорго оказывают различное влияние на урожайность и посевные качества семян, поэтому необходимо изучать различные технологические приемы, сортовую агротехнику сорговых культур, обосновывать необходимость их внедрения в зоне Поволжья.

На семенные и фуражные цели сорт зернового сорго Зернышко сеют широкорядным способом (70 см) с нормой высева 180-200 тыс. шт. на 1 га, на полях, чистых от сорняков, возможен посев сплошным и черезрядным способом, с нормой высева 0,75 млн всхожих зерен на 1 га. Лучший срок посева, когда почва на глубине за- делки зерен прогреется до $12-15^{\circ} \mathrm{C}$. Оптимальная глубина заделки семян 6-8 см, допустима заделка до 8-10 см. После посева необходимо проводить прикатывание. Листья нового сорта имеют светло-зеленую жилку, по мере созревания она светлеет. По уходу за посевами для зоны Поволжья рекомендуются стандартные агротехнические приемы - довсходовое боронование, обработка гербицидами, междурядная обработка на широкорядных посевах.

В технологическом комплексе производства семян сорго сроки уборки занимают одно из важнейших мест. Наиболее существенное влияние на урожайность и посевные качества семян оказывает влажность зерна. Установлено, что посевные качества большинства зерновых колосовых культур наиболее высокими оказываются при раздельном способе уборки. В силу того, что многие сорта сорго вызревают осенью при пониженной температуре и повышенной влажности воздуха, получить семяна высокого качества удается не всегда. В этой связи необходимо разработать приемы уборки сорго, позволяющие стабильно получать семена с хорошими посевными качествами. Уборка на семена и фураж проводится в фазу восковой и полной спелости.

Сорго, как и другие сельскохозяйственные культуры, поражается целым рядом заболеваний бактериальной, вирусной и грибной этиологии, существенно ограничивающих возможность реализации высокого биологического потенциала этой культуры. Среди обширного многообразия болезней сорго наиболее вредоносными являются головневые заболевания: покрытая (зерновая, твердая) - возбудитель Sphacelotheca sorghi (Unk) Clint, пыльная (метельчатая) - возбудитель Sorosporium reilianum McAlp. f. sorgi Gechele и мелкопузырчатая - возбудитель Sphacelotheca cruenta Potter. Эти виды головни не только полностью или частично разрушают генеративные органы, но и оказывают негативное влияние на рост и развитие растений, их фотосинтетическую деятельность, что отрицательно сказывается на формировании урожая зерна и зеленой массы, а также на качестве получаемой продукции.

Потери урожая зерна при поражении растений покрытой головней варьируют от 8,9 до 69,1 \%, мелкопузырчатой - от 21,3 до 46,4 \%, пыльной от 41,9 до 86,4 \%. Потери урожая вегетативной массы при поражении сорго пыльной головней колеблются от 19,2 до 33,8 \% [6, 9]. Устойчивость зернового сорго Зернышко к пыльной головне в сравнении с сортами селекции ФГБНУ «НИИСХ Юго-Востока» и ФГБНУ РосНИИСК «Россорго» изучали в лаборатории иммунитета ФГБНУ «НИИСХ Юго-Востока» (табл. 2). 
Устойчивость сорго зернового Зернышко к пыльной головне на инфекционном фоне в ФБГНУ «НИИСХ Юго-Востока»

\begin{tabular}{|c|c|c|}
\hline Год & Сортообразцы & Доля поражения, \% \\
\hline \multirow{3}{*}{2009} & Зернышко & 0,0 \\
\cline { 2 - 3 } & Солнышко & 0,1 \\
\cline { 2 - 3 } & Волжское 4 & 0,2 \\
\hline \multirow{3}{*}{2010} & Зернышко & 0,0 \\
\cline { 2 - 3 } & Солнышко & 0,1 \\
\cline { 2 - 3 } & Волжское 4 & 0,1 \\
\hline
\end{tabular}

За годы изучения новый сорт зернового сорго Зернышко показал устойчивость к пыльной головне на инфекционном фоне.

Заключение. Сорт Зернышко хорошо выровнен, отличается ускоренными темпами начального роста. Семеноводство сорта надежно. Период от всходов до полной спелости зерна составляет 85-90 дней. Отличается высоким содержанием крахмала - 75,88 \%.

Следует отметить, что уборочная влажность зерна данного сорта в среднем за три года (2008-2010) составила 11,6 \%, при стандартной 13,0 \%, у стандарта Перспективный 1 - 13,7 \%. Этот показатель свидетельствует о скороспелости сорта Зернышко и о том, что периода послеуборочной сушки семян может не быть или он может быть значительно сокращен.

Сорт предназначен для использования на фуражные цели и для производства крахмала. По результатам изучения сорт Зернышко с 2016 г. допущен ГСИ к использованию в Нижневолжском регионе.

\section{СПИСОК ЛИТЕРАТУРЫ}

1. Большаков А.З., Коломиеи Н.Я. Сорго: от селекции к технологии. - Ростов н/Д.: РосИздат, 2003. - 96 с.

2. Вертикова Е.А., Морозов Е.В., Ермолаева Г.И. Оценка исходного материала для создания высокопродуктивных сортов зернового сорго // Аграрный научный журнал. - 2016. - № 11. - С. 12-18.

3. Горбунов С.И. Сорговые культуры как фактор стабилизации кормопроизводства в засушливых районах Юго-Востока России // Научное обеспечение расширения посевов сорговых культур и кукурузы на зерно в засушливых районах Ю.-В. России и стран СНГ: материалы Междунар. науч.-практ. конф., 19-20 сент., 2003. - Саратов, 2004.- С. 3-11.

4. Доспехов Б.А. Методика полевого опыта. - 5-е изд., перераб. и доп. - М.: Агропромиздат, 1985. - 351 с.

5. Землянов А.Н. Научные основы технологии возделывания и семеноводства зернового сорго в засушливых зонах Северного Кавказа: автореф. дис. ... д-ра с.-х. наук. - Ставрополь, 1999. - 46 с.

6. Исаков Я.И. Сорго. - 2-е изд., перераб. и доп. М.: Россельхозиздат, 1982. - 133 с.

7. История создания исходного материала сорго и многолетних трав в ФГБНУ «НИИСХ Юго-Востока» / В.В. Гусев [и др.] //Аграрный Вестник Юго-Востока. 2017. - № 1(16). - С. 18-21.

8. Ишин А.Г., Эльконин Л.А., Тырнов В.С. Сорго: проблемы генетики и селекции. Ч. І. Частная генетика, апомиксис, культура ткани. - Саратов: Изд-во Сарат. ун-та, 1987. - 120 с.

9. Силаев А.И. Биолого-токсилогическое обоснование адаптивной защиты сорго от головневых болезней в Поволжье: автореф. дис. .... канд. биол. наук. - СПб., 2005. - 46 c.

10. http://ab-centre.ru/page/selskoe-hozyaystvosaratovskoy-oblasti.

Гусев Владимир Васильевич, канд. с.-х. наук, ведущий научный сотрудник, ФГБНУ НИИСХ «Юго-Востока». Россия.

Халикова Мадина Мустапаевна, канд. с.-х. наук, старший научный сотрудник, ФГБНУ НИИСХ «Юго-Востока». Россия.

Ескова Вера Сергеевна, канд. с.-х. наук, научный сотрудник, ФГБНУ НИИСХ «Юго-Востока». Россия.

Ларина Валентина Владимировна, старший научный сотрудник, ФГБНУ НИИСХ «Юго-Востока». Россия.

Бахарева Наталья Викторовна, младиий научный сотрудник, ФГБНУ НИИСХ «Юго-Востока». Россия.

Храмов Александр Владимирович, научный сотрудник, ФГБНУ НИИСХ «Юго-Востока». Россия.

410010, г. Саратов, ул. Тулайкова, 7.

Тел.: (8452) 64-77-39.

Ключевые слова: сорго; селекиия; технология; качество; урожайность.

\section{NEW VARIETY OF GRAIN SORGO 'ZYORNYSHKO”}

Gusev Vladimir Vasylyevich, Candidate of Agricultural Sciences, Leading Researcher, Agricultural Research Institute for South-East Region. Russia.

Khalikova Madina Mustapaevna, Candidate of Agricultural Sciences, Senior Researcher, Agricultural Research Institute for South-East Region. Russia.

Eskova Vera Sergeevna, Candidate of Agricultural Sciences, Researcher, Agricultural Research Institute for South-East Region. Russia.

Larina Valentina Vladimirovna, Senior Researcher, Agricultural Research Institute for South-East Region. Russia.

Bakhareva Natalya Viktorovna, Younger Researcher, Agricultural Research Institute for South-East Region. Russia.

Khramov Aleksandr Vladimirovich, Researcher, Agricul- tural Research Institute for South-East Region. Russia.

Keywords: sorghum; breeding; technology; quality; yield.

Sorghum is one of the most yielding feed crops in the arid regions of Russia. New grade of grain sorghum "Zyornyshko" has an increased yield, lower moisture grain content when harvesting. Over the years of study, the grain yield of the cv. Zernyshko exceeded the registered standard cv. Perspektivnyi 1 by $1.63 \mathrm{t} / \mathrm{ha}$ with the grain's harvest moisture content 11.6\%, in comparison with $13.7 \%$ in Perspektivnyi 1. It exceeds the standard by $3.35 \%$ on starch content (75.88\%). Seed breeding is reliable. The variety is intended for forage use and for starch production. 